\title{
Performance Analysis of FIS and ANFIS based MPPT for Solar PV System with Boost, SEPIC and CUK Converter Topologies
}

\author{
Mohak Jain \\ Department of Electrical Engineering \\ Delhi Technological University
}

\author{
Bharat Bhushan \\ Department of Electrical Engineering \\ Delhi Technological University
}

\begin{abstract}
This paper works on the performance comparison of PV system implemented with three different DC/DC converter topologies named Boost, Cuk and SEPIC converters. Along with these three converters the MPPT techniques used for maximum power point tracking are FIS and ANFIS. The whole PV system is incorporated with these two soft computing techniques and three converters and voltage variation results have been obtained accordingly, then these results are compared simultaneously to evaluate the overall performance of the PV system in each case
\end{abstract}

\section{Keywords}

PV panel, MPPT techniques, FIS, ANFIS, Boost converter, cuk converter, SEPIC converter

\section{INTRODUCTION}

Solar PV system is a very broad and very relevant topic. Many research papers have already been published in the field of MPPT algorithms such as comparison of classical MPPT approaches such as Perturb and Observe Technique and Incremental conductance, or Fuzzy logic and neural network, some of the research has also be completed in suggesting the new algorithms for MPPT, also work has been done in the field of converters related to PV system and grid connected PV array. In paper[1] the study of battery charge controller used in standalone photovoltaic system has been done as it is a major component of standalone PV system. In [2] a soft computing technique that is adaptive neuro fuzzy inference system has been studied, in [3] also same soft computing technique ANFIS has been covered whereas [4] presents the application of ANFIS on the intelligent systems however [5] talks about the MPPT techniques when implemented on solar vehicle the complete simulation with analysis has been covered in this research work, now [6] covers the controlling of induction motor drives used in various types of applications, in [7] MPPT tracking using fuzzy logic controller when applied to a grid connected PV system has been discussed, however [8] works on the designing and proper selection of parameters of PV system for the production of electricity in Malaysia, in [9] application of large number of PV modules for distribution of energy in urban areas has been covered whereas in [10] a complete case study on the renewable power of malyasia has been studied, in next [11] neural based MPPT for PV system connected with boost converter was studied

\section{MAXIMUM POWER POINT}

Maximum Power Point Tracking, generally referred to as MPPT, drives solar PV array to operate in such a manner that maximum power which can be generated by PV module or array can be extracted fully to transfer it further. MPPT is not any mechanical device or mechanical technique to extract power but it works on control algorithm specially designed for a particular task. MPPT can be used along with with a mechanical tracking system, but both the systems act differently in case of power tracking. MPPT algorithms use the variation of irradiance and temperature to obtain or extract the maximum power from solar PV array. The voltage at which PV array can gives maximum power is called 'maximum power point' (or peak power voltage). Maximum power depends on solar radiation, ambient temperature and varies accordingly to the changes of these parameters. A characteristic PV module generates power having maximum power voltage of around $17 \mathrm{~V}$ measured when temperature of the cell is 25 degree Celsius, it can go down up to $15 \mathrm{~V}$ on a very hot day and it can also elevate to $18 \mathrm{~V}$ on a very cold day. The first and foremost principle of MPPT is to extract maximum power from the PV module by the application of suitable algorithm. MPPT Algorithm operates on the simple logic that, MPPT calculates the output of PV module, then compares it to voltage of battery then fix the optimum power which can be generated by PV module which helps in charging of battery and then converts it to the suitable voltage to obtain maximum current into battery. It can also use to supply power to a DC load, which is connected directly to the battery. MPPT is generally used to charge the deep discharged batteries mostly on cloudy days or time of faults

\section{MPPT TECHNIQUES}

\subsection{Fuzzy Inference System}

Fuzzy logic controller is generally composed of three independent processes which are: fuzzification, second is the rule base operation, and finally defuzzification as we have to convert fuzzy data again into crisp form. In whole fuzzification process, crisp or numerical data that is input variables are transformed into linguistic variables with the help of a membership function. Some of the linguistic variable used in this project are: NB (Negative Big), ZE (Zero) and PB (Positive Big). In Figures 1, 2, 3 given below we can clearly observe the membership functions for two inputs and output. The inputs to a Fuzzy system used as MPPT are generally an error $\mathrm{E}$ and the second one is change in error CE.. As $\mathrm{dP} / \mathrm{dV}$ diminish at the maximum power point, the following approximation can be made.

$\mathrm{E}(\mathrm{n})=\mathrm{P}(\mathrm{n})-\mathrm{P}(\mathrm{n}-1) / \mathrm{V}(\mathrm{n})-\mathrm{V}(\mathrm{n}-1)$

$\mathrm{CE}(\mathrm{n})=\mathrm{E}(\mathrm{n})-\mathrm{E}(\mathrm{n}-1)$

Once the value of $E$ and $C E$ are evaluated the rules can be applied to these linguistic variable according to the form stated in rule base the value of output which is usually a duty cycle that is provided to converter can be obtained. The inference system used in this case is mamdani. The selection of linguistic variables that are used to represent $\mathrm{dD}$ for the 
different combinations of $\mathrm{E}$ and $\mathrm{CE}$ is totally depends on the data collected or analysed by the user. In the final defuzzification process, the fuzzy controller output which is obtained from linguistic variable is converted again to numerical value or crisp data with the help of membership functions. The defuzzification process generates an analog function in the form of output which is given to the converter in the form of duty cycle to drive the system. MPPT implemented using fuzzy logic controller gives best results when operate under atmospheric conditions. But their overall efficiency depends majorly on the data of controller or engineer or the user by correct computation of error using the rule base as shown in figure 4 .

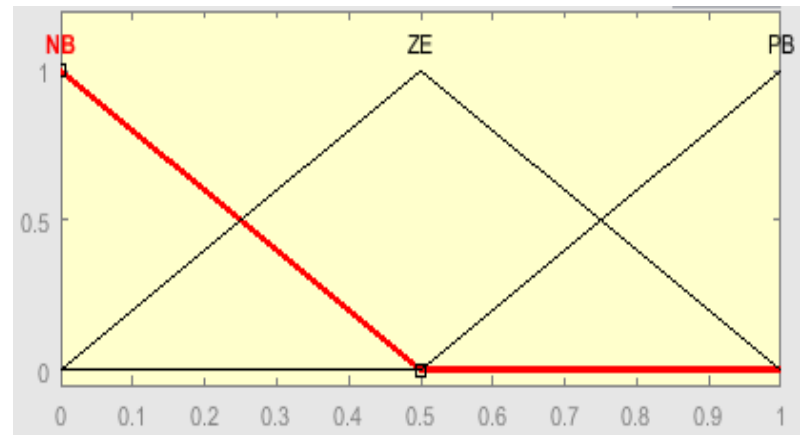

Figure 1: Membership functions for input variable (E)

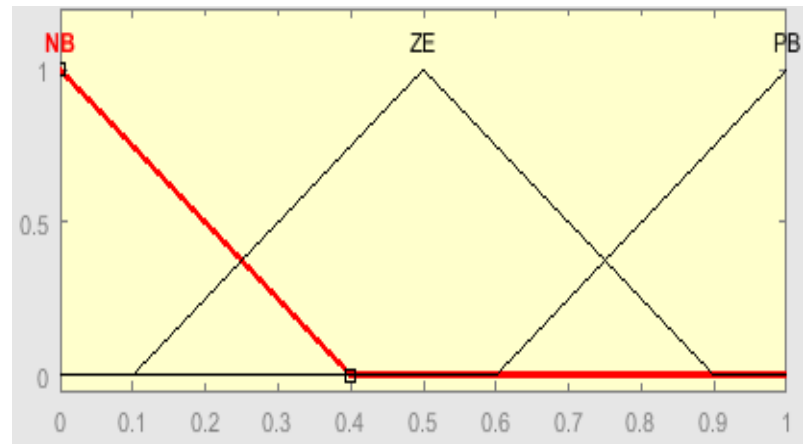

Figure 2: Membership function of input variable (CE)

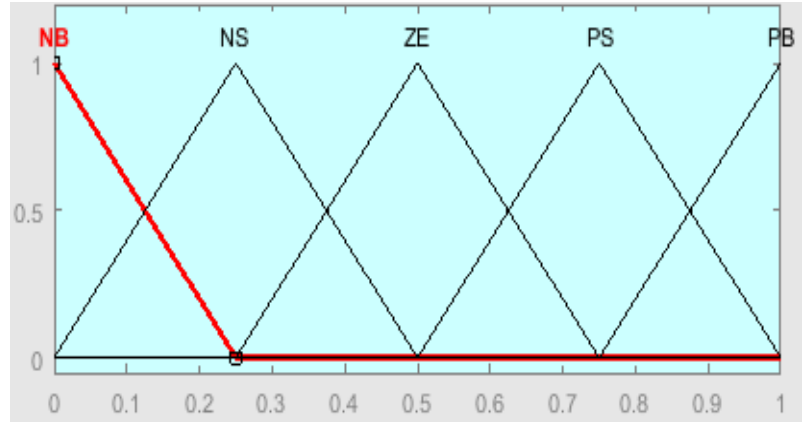

Figure 3: membership function of output variable (dD)

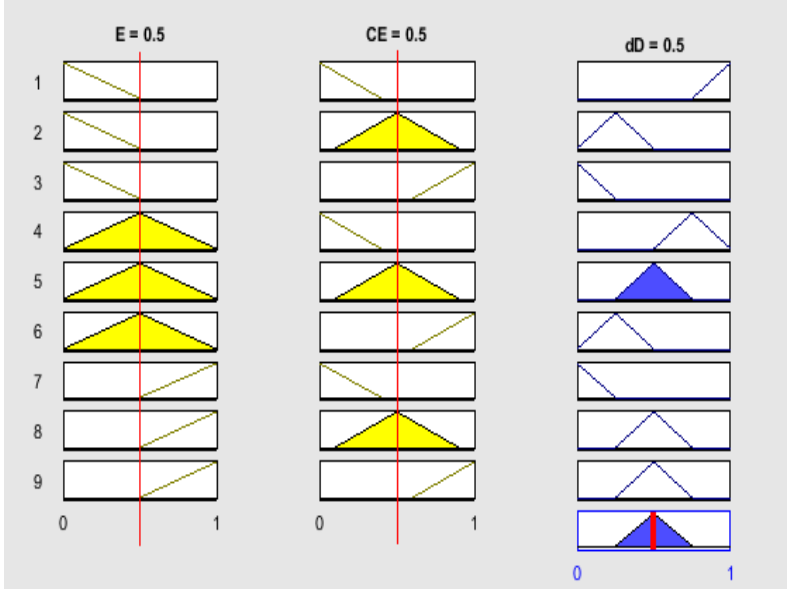

Figure 4: Rule viewer of rule base

\subsection{ANFIS based MPPT}

Over the past few years there has been a great development in the field of information based on non-linear network. These complex and broad systems cannot be explained or made to work with only one of the controlling techniques hence we require some more efficient way to complete this. One of the algorithm to manage these complex issues is combination of two or more system to accomplish a pre define goal and to overcome the shortcomings of previous controlling methodology. Fuzzy logic is a good tool for displaying uncertainties and approximate reasoning, on the other hand neural network is the best machine in field of learning. Adaptive neuro fuzzy inference system combines the point of interests of fuzzy logic and neural network in one and produce enhanced fuzzy framework which is incorporated with learning mechanism of neural network and hence more efficient. For PV cells also we can create a cross breed system that joins fuzzy logic and neural network to detect the maximum power point.

In this firstly we collect the data of different values of irradiance and temperature and output of panel accordingly which is fed into neuro fuzzy designer and with then help of this data sugeno inference system type fuzzy logic is designed with neural network incorporated in that. We can clearly see the trained rule viewer of FIS in figure 5.

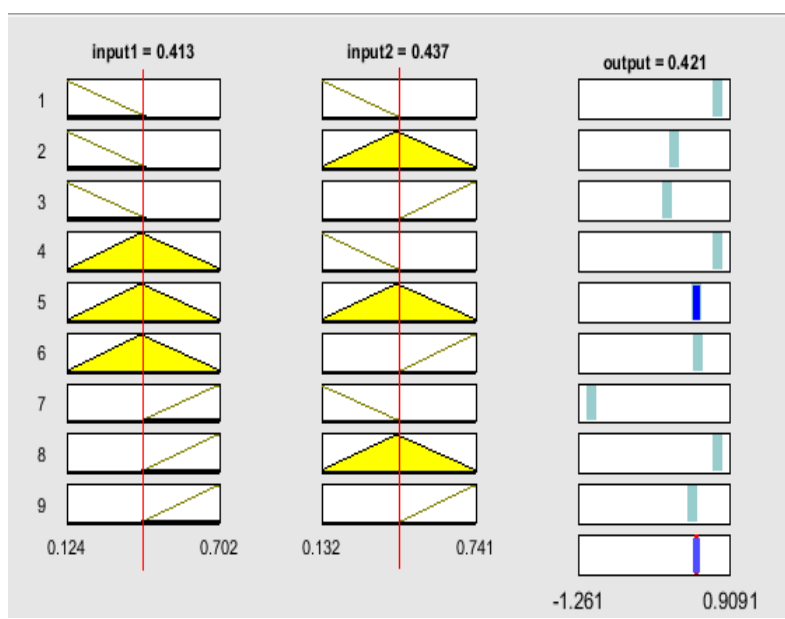

Figure 5: Rule Viewer of trained FIS 
The trained ANFIS model is shown in figure 6 along with the final ANFIS system shown in figure 7.

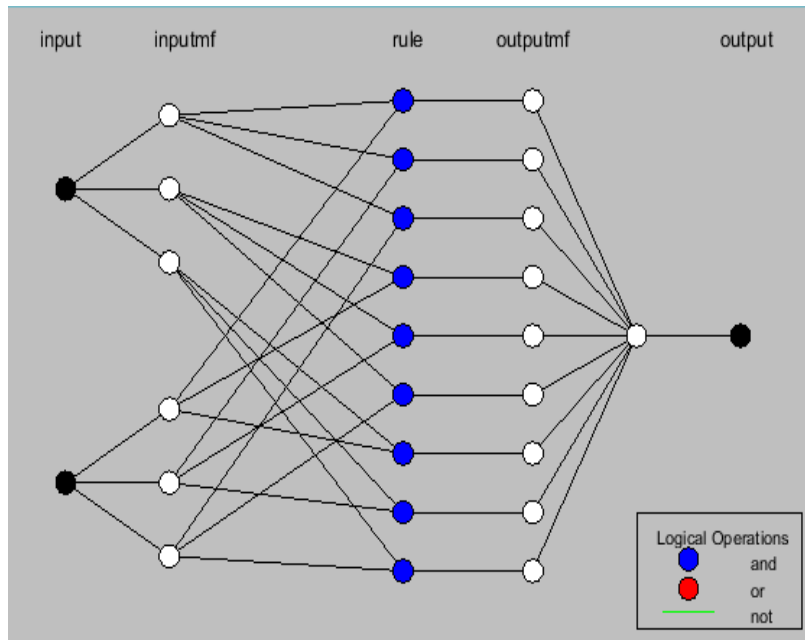

Figure 6: ANFIS model structure

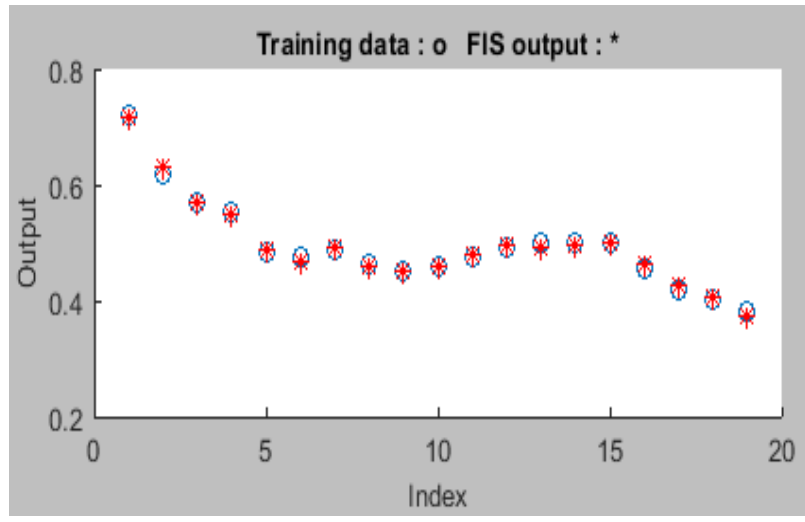

Figure 7: Final Tested ANFIS system

\section{DC/DC Converters}

A DC to DC converter takes the voltage from a DC source and converts the voltage of supply into another DC voltage level. They are used to increase or decrease the voltage level. The DC/DC converter is mostly used in portable DVD players, automobiles and portable chargers. As most of the equipments need certain range or level of voltage to operate as very high voltage can damage that device and very low voltage cannot make it to run so for such cases a converter is used as it can takes power from the PV panel and varied the voltage by stepping up or stepping down it to a certain level.

\subsection{Boost Converter}

A boost converter as shown in figure 8 is used to convert the unregulated direct current input voltage, generated by a PV module to a controlled DC voltage with value higher than the input as required by the load that is it boost the voltage value of input and hence named as boost converter. This conversion of voltage is generally perform by applying a DC voltage across an inductor, for a period of time (usually in range of $20 \mathrm{kHz}$ to $5 \mathrm{MHz}$ ) that produces current which flow through it and stores energy magnetically, and then we switch OFF this voltage which results in the transfer of stored energy to the output voltage in controlled way. This voltage is regulated by adjusting the duty cycle. To achieve this fast switching power electronics component like IGBT or MOSFET is used as they dissipate least power. Pulse width modulation (PWM) technique is use to control and regulate total output voltage.
The ideal boost converter possess $100 \%$ efficiency but in general $70 \%$ to $90 \%$ of efficiency is obtained.

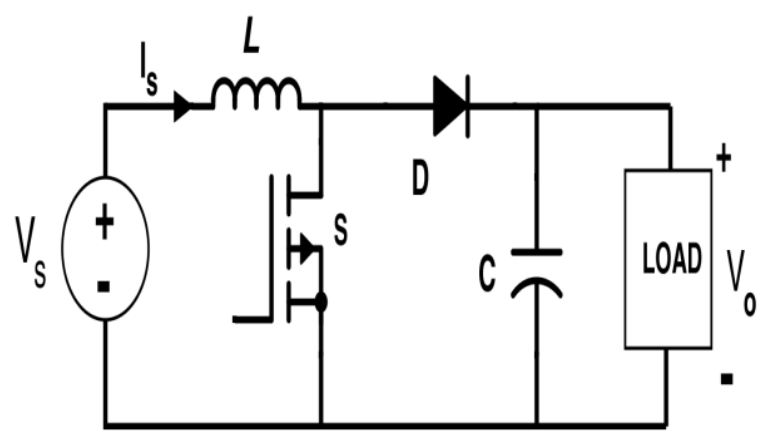

Figure 8: Boost converter

The boost converter as shown in the figure has a constant DC input voltage source Vs, boost inductor L, controlled switch S, diode $\mathrm{D}$, filter capacitor $\mathrm{C}$ and a load.

DC voltage gain of converter is given as:

$$
G=\frac{V_{0}}{V_{S}}=\frac{1}{1-\alpha}
$$

Selection of inductor-Inductor with large value increases the startup time slightly whereas low inductance value allow the coil current to increase up to very high values before the switch turns OFF. It is selected on the basis of the maximum allowed ripple current at minimum duty cycle and maximum supply voltage. Boost converter works in continuous conduction mode for inductor value $\mathrm{L}>\mathrm{L}_{\mathrm{c}}$ where $\mathrm{L}_{\mathrm{c}}$ is a critical inductance value and is given by

$$
L_{c}=\frac{\left(1-\alpha^{2}\right) * \alpha * R}{2 f_{S}}
$$

where $R$ is the load resistance and $f_{s}$ is the switching frequency of converter.

Selection of capacitor-the current supplied to the RC circuit is discontinuous that's why a larger filter capacitor is required to decrease the ripples in output voltage. The primary way to select filter capacitor is its capacitance and it's series resistance as this series resistance affects efficiency, low ESRcapacitors is used for best performance. The filter capacitor is use to decrease the ripples in output voltage. Minimum value of filter capacitor that allow current to flow through load when diode is OFF is given by

$$
C_{\min }=\frac{V_{o} * \alpha}{f_{S} * \Delta V_{o} * R}
$$

Where $\Delta V_{o}$ is the ripple in output voltage which is generally $5 \%$ of output voltage

\subsection{Cuk Converter}

A CUK converter as shown in figure 9 is an another type of DC/DC converter which produce output voltage either greater or lesser than the input voltage. It is actually a boost converter which is followed by a buck converter. The main difference is that it consists of an additional capacitor to store energy. As the buck-boost converter produces an inverted output similarly cuk converter also produces an inverted output which can be either higher or lower than the input. As most of 
the converters use inductor as their main energy storage element it uses an additional capacitor to store energy

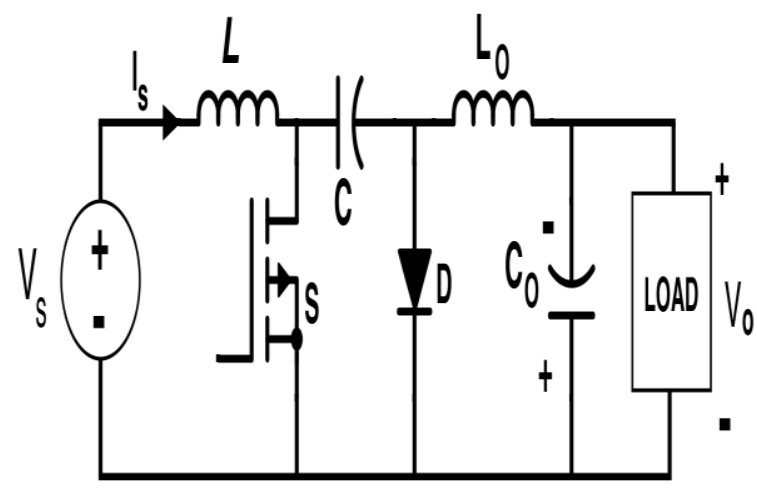

Figure 9: Cuk converter

A cuk converter basically consist of two capacitor, two inductors, one switch and one diode. The transfer of energy is done with the help of capacitor $\mathrm{C}$ and two inductors $\mathrm{L}$ and $\mathrm{L}_{0}$ are used to convert input voltage source and output voltage source respectively into current source. The conversion of voltage source into current source is necessary because if capacitor is directly connected to resistance then it will cause high energy loss in the system

Now if we apply voltage sec balance across $L$

$$
\begin{aligned}
& V_{s} \alpha T+\left(V_{s}-V_{c}\right)(1-\alpha) T=0 \\
& \therefore \quad V_{s}(1-\alpha) V_{c}=0 \\
& \text { Or } \quad V_{c}=\frac{V_{s}}{1-\alpha}
\end{aligned}
$$

Applying voltage sec balance across $\mathrm{L}_{0}\left(V_{0}+V_{c}\right) \alpha T+$ $V_{0}(1-\alpha) T=0$

$V_{0}+\alpha V_{c}=0$

$V_{0}=-\alpha V_{c}=-\frac{\alpha V_{s}}{1-\alpha}$

Similarly current through two inductors $\mathrm{L}$ and $\mathrm{L}_{0}$ are stated as follow

$$
I=\frac{\alpha^{2}}{(1-\alpha)^{2}} \frac{V_{s}}{R}, I_{0}=\frac{\alpha}{1-\alpha} \frac{V_{S}}{R}
$$

So basically cuk converter combines the features of both boost and buck-boost converter hence it has following advantages

1. It provide continuous input current

2. It provide continuous output current

3. Output voltage obtained can be higher or lower than input voltage.

\subsection{SEPIC Converter}

A SEPIC converter or single-ended-primary-inductorconverter is also a DC/DC converter that gives output voltage either higher, lower or equal to the input voltage. It is actually a boost converter followed by a buck-boost converter. The major advantage of SEPIC converter over buck boost converter that unlikely buck boost converter it produces a non-inverting voltage output. It uses a series capacitor for energy coupling from input to output and hence can give better results when used in short circuit condition. Unlike cuk converter it has pulsating output which is one of the disadvantage of SEPIC converter, also its fourth order nature make it suitable for slow varying systems only. A detailed circuit diagram of SEPIC converter is shown in figure 10.

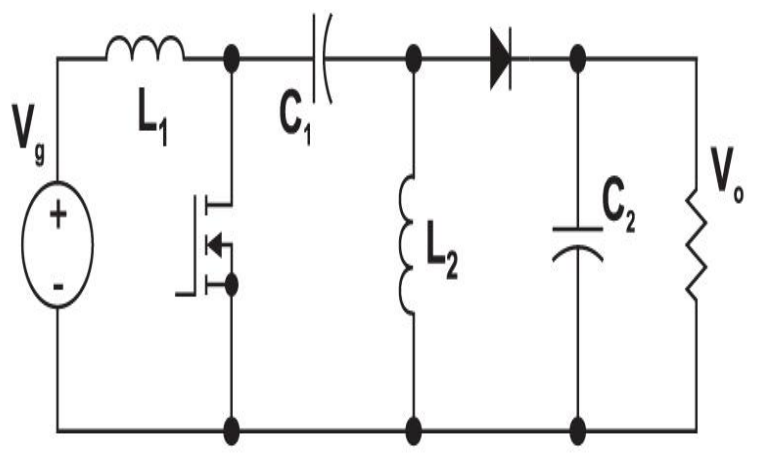

Figure 10: SEPIC converter

During the turn ON time the diode gets reverse biased and coupling capacitor has negative polarity which helps in charging of inductor $\mathrm{L}_{1}$ and $\mathrm{L}_{2}$ via source and coupling capacitor gets discharge on the other hand in case of turn OFF time the diode gets forward biased and inductor $\mathrm{L}_{1}$ helps in the charging of coupling capacitor whereas inductor $\mathrm{L}_{2}$ transfer its stored energy to the output and this is how an SEPIC converter works.

Duty cycle selection-for continuous mode operation duty cycle is given by

Output of a SEPIC converter is given by

$$
V_{0}=\frac{\alpha * V_{g}}{1-\alpha}
$$

If we consider losses due to voltage drop across diode then output can be stated as-

$V_{0}+V_{D}=V_{0}=\frac{\alpha * V_{g}}{1-\alpha}$

Due to this final expression of duty cycle becomes

$$
\alpha=\frac{V_{0}+V_{D}}{V_{g}+V_{0}+V_{D}}
$$

Inductor calculation- inductors are basically used in converters to produce a ripple free output.

The ripple current flowing through $\mathrm{L}_{1}$ and $\mathrm{L}_{2}$ is given by

$40 \%$

$$
\Delta I_{L}=I_{\text {in }} * 40 \%=I_{0} * \frac{V_{0}}{V_{g}} *
$$

The value of two inductors can be calculated as $L_{1}=L_{2}=$ $L=\frac{V_{g, \min }}{\Delta I_{L} * f_{s}} * \alpha_{\max }$

Coupling capacitor calculation- The value of capacitor depends on RMS current whose expression is given as-

$I_{c 1, r m s}=I_{0} * \sqrt{\frac{V_{0}+V_{D}}{V_{g, \min }}}$

Peak to peak ripple voltage can be given as 


$$
\Delta V_{c S}=\frac{I_{0} * \alpha_{\max }}{C * f_{S}}
$$

\section{SIMULATION AND RESULTS}

The basic Block Diagram of whole system on which analysis is done is shown in figure 11 below, it is divided into three parts the first one is PV array then the second art is DC/DC converter which is getting the gate pulse through the MPPT technique which has been applied to extract maximum power from the PV panel and the third segment is conversion of converter output into AC supply through which is supplied to the grid.

Table 1. Technical Specifications of PV array

\begin{tabular}{|c|c|}
\hline TECHNICAL & VALUE \\
SPECIFICATIONS & \\
\hline Cells Per Module & 60 \\
\hline Open circuit voltage $\left(\mathrm{V}_{\mathrm{oc}}\right)$ & $36.96 \mathrm{~V}$ \\
\hline Short circuit current $\left(\mathrm{I}_{\mathrm{sc}}\right)$ & $8.49 \mathrm{~A}$ \\
\hline Maximum power & $240.694 \mathrm{~W}$ \\
\hline Voltage at MPP $\left(\mathrm{V}_{\mathrm{mp}}\right)$ & $30.2 \mathrm{~V}$ \\
\hline Current at MPP $\left(\mathrm{I}_{\mathrm{mp}}\right)$ & $7.97 \mathrm{~A}$ \\
\hline
\end{tabular}

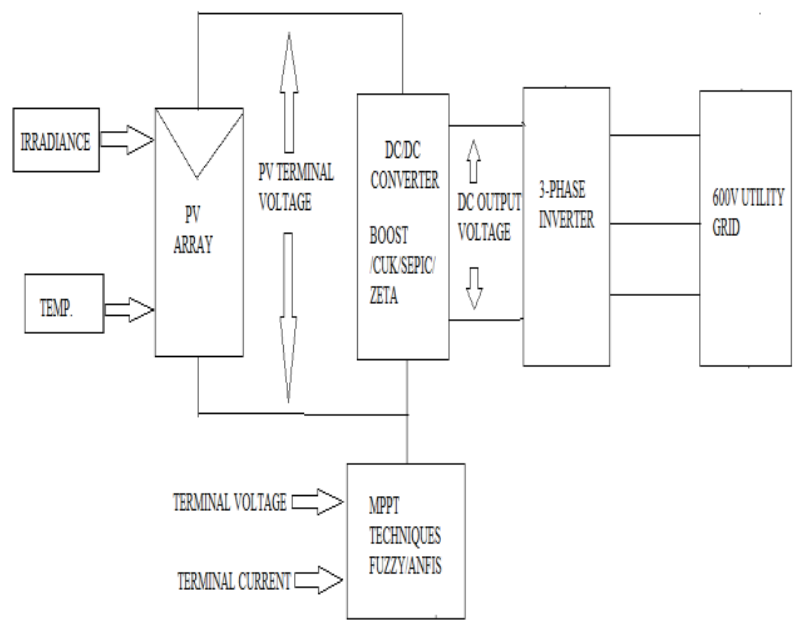

Figure 11: Schematic block diagram of system

The Panel which is selected for analysis is one of the specified panels of MATLAB/SIMULINK library and that is Neo Solar Power D6P240B3A, in this project five parallel string with four panel in series connected in each string is taken into consideration for analysis. Hence we have an array of 20 such modules. Technical specifications of this panel is shown below:

The two major inputs to PV array are irradiance and temperature. In this project analysis is done for three different values of irradiance and temperature. For the daytime the value of irradiance is $600 \mathrm{~W} / \mathrm{m}^{2}$ and temperature is $25^{\circ} \mathrm{C}$. For noontime the irradiance value is taken as $1000 \mathrm{~W} / \mathrm{m}^{2}$ and temperature is $45^{\circ} \mathrm{C}$ and for evening time the value of irradiance is set at $400 \mathrm{~W} / \mathrm{m}^{2}$ and temperature is taken as $32^{\circ} \mathrm{C}$. These values are plot using signal builder in MATLAB as shown in figure 12 and 13.

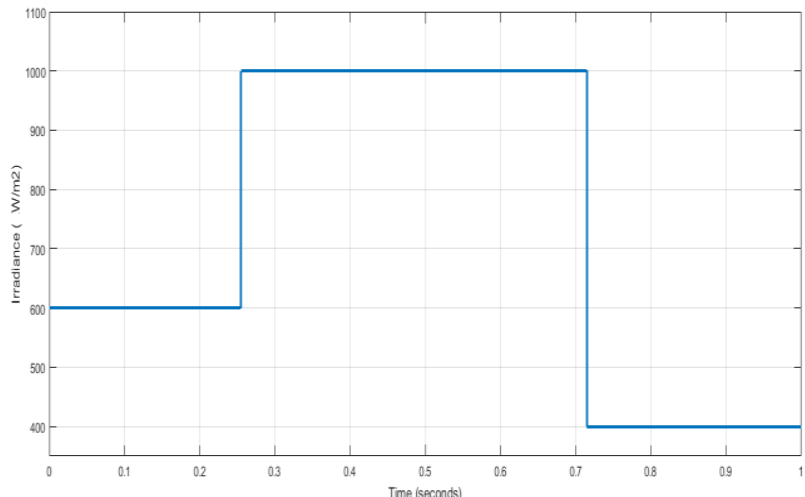

Figure 12: Irradiance plot for three different values

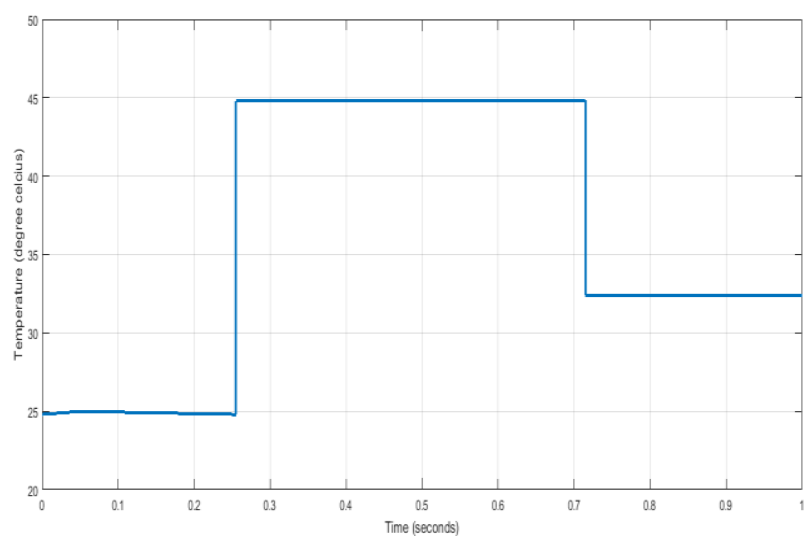

Figure 13: Temperature variation

\subsection{PV system with boost converter}

The voltage variation of PV output and output of converter is shown in figure 14 for FIS and figure 15 for ANFIS

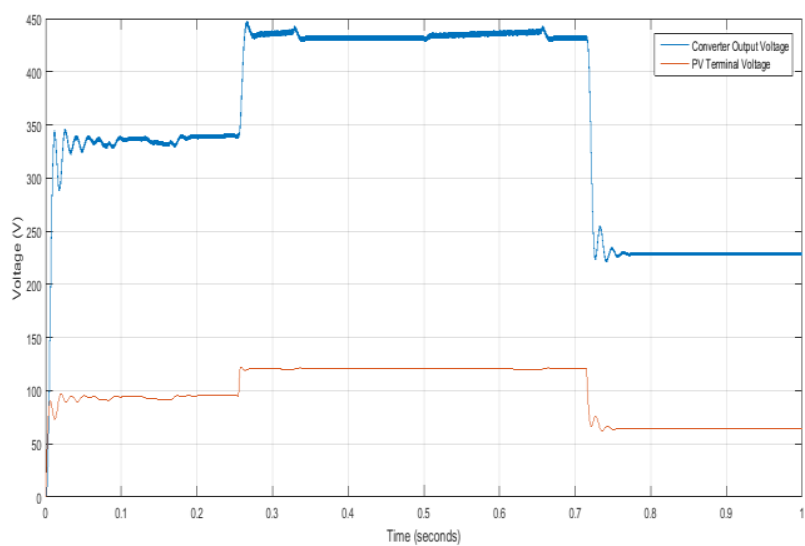

Figure 14: Voltage variation for FIS based MPPT

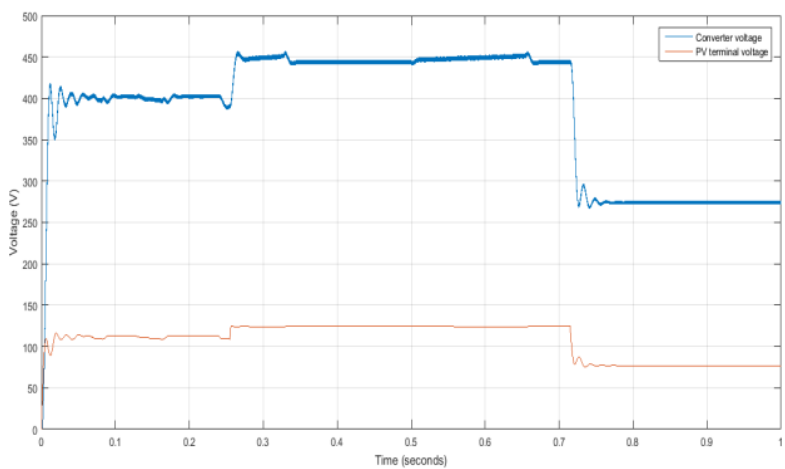

Figure 15: Voltage variation for ANFIS based MPPT 
Table 2. Boost converter performance comparison

\begin{tabular}{|c|c|c|c|}
\hline $\begin{array}{c}\text { MECHN } \\
\text { ES }\end{array}$ & $\begin{array}{c}\text { PV } \\
\text { IRRADIANC } \\
\text { E/TEMP. }\end{array}$ & $\begin{array}{c}\text { TERMINAL } \\
\text { VOLTAGE } \\
(\mathrm{V})\end{array}$ & $\begin{array}{c}\text { CONVERTE } \\
\text { R OUTPUT } \\
\text { VOLTAGE }\end{array}$ \\
\hline \multirow{3}{*}{ FUZZY LOGIC } & $1000 / 45$ & 109.9 & 392.5 \\
\cline { 2 - 4 } & $400 / 32$ & 80.2 & 286.42 \\
\hline \multirow{3}{*}{ ANFIS } & $600 / 25$ & 108.2 & 386.42 \\
\cline { 2 - 4 } & $1000 / 45$ & 110 & 392.85 \\
\cline { 2 - 4 } & $400 / 32$ & 98.6 & 352.14 \\
\hline
\end{tabular}

\subsection{PV system with Cuk converter}

Voltage output for cuk converter is shown in figures 16 and 17 for FIS and ANFIS based MPPT respectively

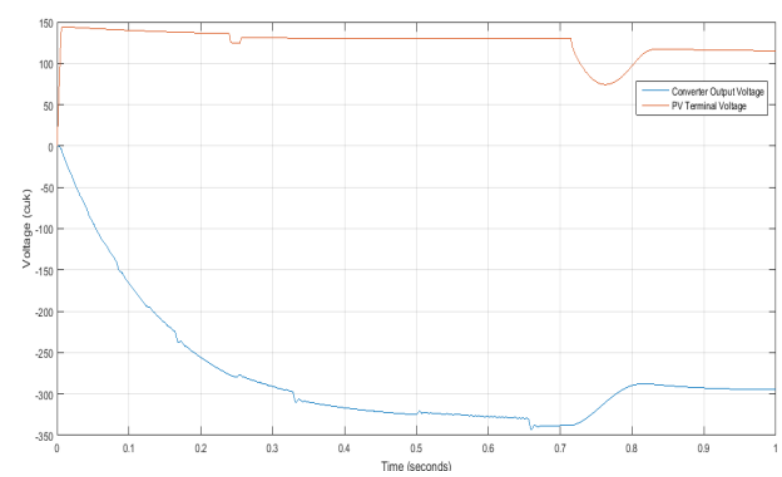

Figure 16: Voltage variation for FIS based MPPT

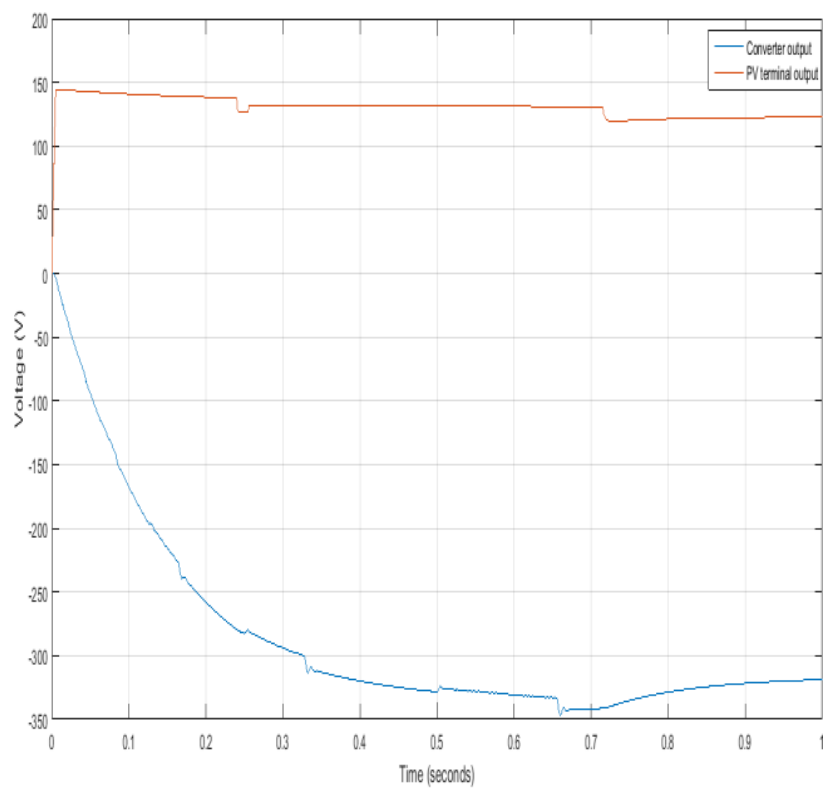

Figure 17: Voltage variation for ANFIS based MPPT
Table 3.Cuk converter performance comparison

\begin{tabular}{|c|c|c|c|}
\hline \multirow{2}{*}{ MPCHNIQUES } & $\begin{array}{c}\text { IRRADIA } \\
\text { NCE/TEM } \\
\text { P. }\end{array}$ & $\begin{array}{c}\text { PV } \\
\text { TERMIN } \\
\text { AL } \\
\text { VOLTAG } \\
\text { E } \\
(\mathrm{V})\end{array}$ & $\begin{array}{c}\text { CONVER } \\
\text { TER } \\
\text { OUTPUT } \\
\text { VOLTAG } \\
\text { E }\end{array}$ \\
\hline \multirow{3}{*}{ FUZZY LOGIC } & $1000 / 45$ & 108.2 & -307.28 \\
\cline { 2 - 4 } & $400 / 32$ & 105.6 & -299.90 \\
\cline { 2 - 5 } & $600 / 25$ & 120 & -340.8 \\
\cline { 2 - 5 } & $1000 / 45$ & 109.4 & 310.69 \\
\cline { 2 - 5 } & & 119.1 & -338.24 \\
\cline { 2 - 5 } & $400 / 32$ & 107.4 & -305.01 \\
\hline
\end{tabular}

\subsection{PV system with SEPIC converter}

The output waveforms for FIS and ANFIS based MPPT is shown in figure 18 and 19 respectively

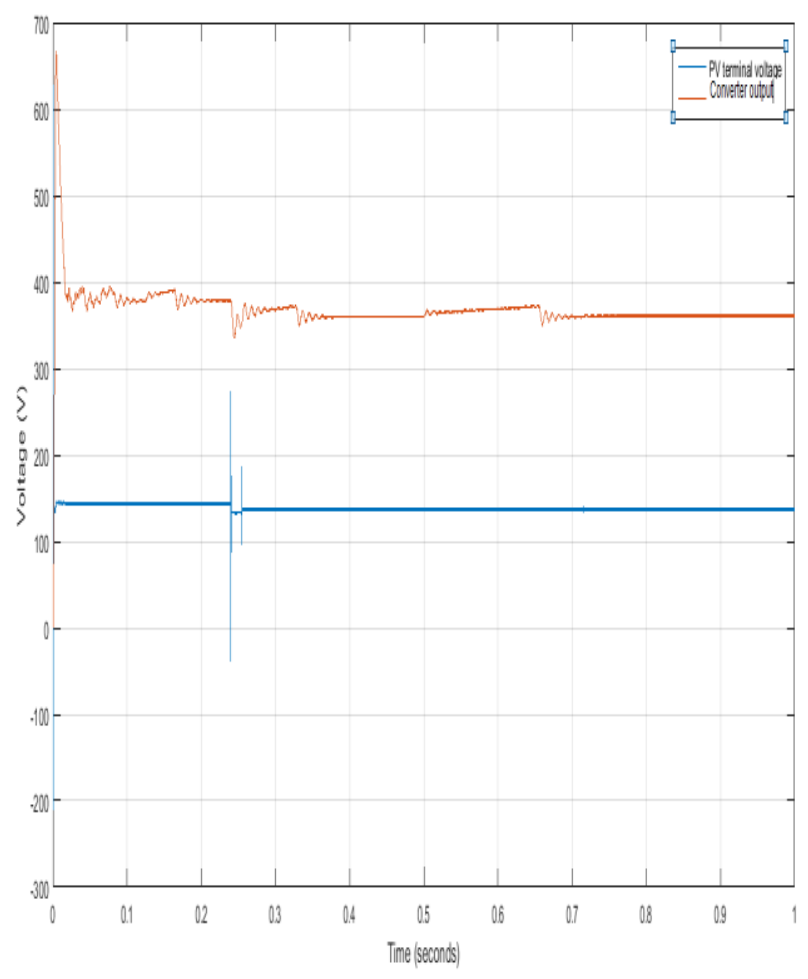

Figure 18: Voltage variation for FIS based MPPT 


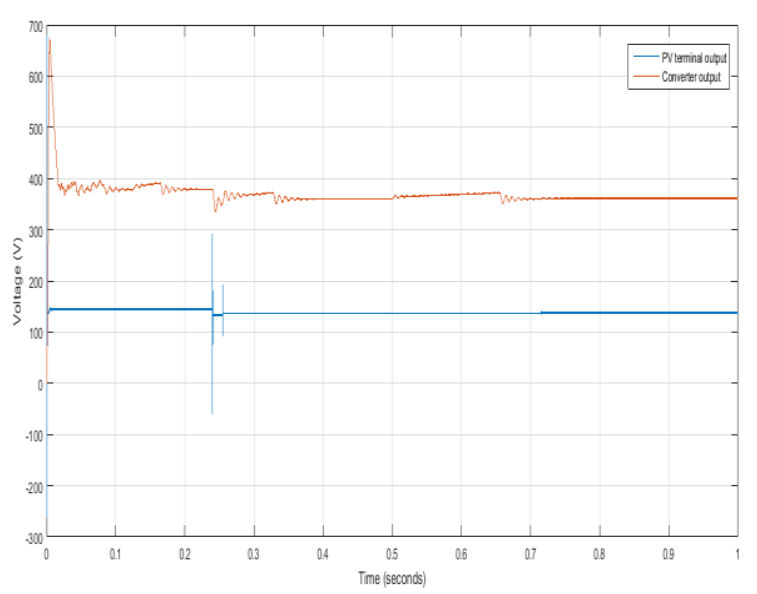

Figure 19: Voltage variation for ANFIS based MPPT

Table 4. SEPIC converter performance comparison

\begin{tabular}{|c|c|c|c|}
\hline \multirow{4}{*}{$\begin{array}{c}\text { MPPT } \\
\text { TECHNIQUES }\end{array}$} & $\begin{array}{c}\text { PRV } \\
\text { /TEMP. }\end{array}$ & $\begin{array}{c}\text { TERMINAL } \\
\text { VOLTAGE } \\
(\mathrm{V})\end{array}$ & $\begin{array}{c}\text { CONVERTE } \\
\text { R OUTPUT } \\
\text { VOLTAGE }\end{array}$ \\
\hline \multirow{4}{*}{ FUZZY LOGIC } & $1000 / 45$ & 109.7 & 358.2 \\
\cline { 2 - 4 } & $400 / 32$ & 108.3 & 349.1 \\
\cline { 2 - 4 } & $600 / 25$ & 110 & 358.4 \\
\cline { 2 - 4 } & $1000 / 45$ & 109.7 & 370.9 \\
\cline { 2 - 4 } ANFIS & $400 / 32$ & 109 & 352.5 \\
\cline { 2 - 4 } & & & \\
\hline
\end{tabular}

\section{CONCLUSIONS}

From the above work it can be concluded that the performance of ANFIS based MPPT is slightly better than FIS based MPPT in achieving the maximum power point. Also if we talk about the converters then each configuration boost up the voltage according to the parameters of its components and duty cycle but the variations in voltage are more in case of boost converter due to change in values of temperature and irradiance whereas voltage is almost constant in case of cuk and SEPIC converter.in case of cuk converter the output generated is inverted one whereas in case of SEPIC the ripple content is very high hence for stable output we can use cuk converter or SEPIC Converter whereas for ripple free voltage boost converter can be used.

\section{REFERENCES}

[1] Harrington S, Dunlop J (1992) Battery charge controller characteristics in photovoltaic systems. In: Proceedings of the 7th annual battery conference on advances and applications. Long Beach, California, 21 Jan 1992

[2] Jang, J.-S.R. (1993). "ANFIS: adaptive-network-based fuzzy inference system". IEEE Transactions on Systems, Man and Cybernetics 23 (3). doi:10.1109/21.256541, 1993.

[3] Borowy BS, Salameh ZM (1996) Methodology for optimally sizing the combination of a battery bank and PV array in a wind/PV hybrid system. IEEE Trans Energy Conv 11(2):367-375

[4] Lin C-T, Lee CSG (1996) Neural fuzzy systems: a neurofuzzy synergism to intelligent systems. Prentice-Hall, Upper Saddle River

[5] H. Knopf, "Analysis, Simulation, And Evaluation of Maximum Power Point Tracking (MPPT) Methods for a solar power vehicle," in Electrical and Computer Engineering, vol. Master of Science in Electrical and Computer Engineering: Portland State University 1999, pp. 177.

[6] A.M. Khambadkone, and J. Holtz, "Current Control in Over-modulation Range for Space Vector Modulation based Vector Controlled Induction Motor Drives," IEEE Industrial Electronics Society, Vol.2, pp. 1134- 1339, 2000.

[7] N. Patcharaprakitia, and al. "Maximum power point tracking using adaptive fuzzy logic control for gridconnected photovoltaic system", in IEEE Power Eng. SocietyWinter Meeting,2002, pp. 372-377.

[8] Ahmed MM, Sulaiman M (2003) Design and proper sizing of solar energy schemes for electricity production in Malaysia. National Power and Energy Conference 2003, pp 268-271

[9] Conti S, Raiti S, Tina G, Vagliasindi U (2003) Integration of multiple PV units in urban power distribution systems. Sol Energy 75:87-94

[10] A. Zain-Ahmed, K. Sopian, Z. Zainol Abidin and M. Y. H. Othman, "The Availability of Daylight from Tropical Skies - A Case Study of Malaysia", Renewable Energy, Vol.28, Issue 15, pp. 2355-2365, December 2003.

[11] M. Veerachary, T. Senjyu, and K. Uezato, -Neuralnetwork-based maximum- power-point tracking of coupled-inductor interleaved boost converter-supplied 